СПОРТСКЕ АКТИВНОСТИ ОСОБА СА ИНВАЛИДИТЕТОМ И АРХИТЕКТОНСКЕ БАРИЈЕРЕ

\author{
Драгана Кљајић ${ }^{1}$, Фадиљ Еминовић², Слађана Арсић ${ }^{3}$, Марија Трајков $^{4}$
}

\title{
SPORTS ACTIVITIES OF PERSONS WITH DISABILITIES AND ARCHITECTURAL BARRIERS
}

Dragana Kljajić, Fadilj Eminović, Slađana Arsić, Marija Trajkov

\section{Сажетак}

Увод: Реализащија спортских активности особа са инвалидитетом захтева пре свега приступачност спортских објеката и спортских терена. Архитектонске баријере су просторне препреке унутар изграђеног окружења које корисницима инвалидских колича ограничавају или у потпуности онемогућавају юихову самосталну употребу.

Циљ истраживана је био да се испита на које архитектонске баријере наилазе особе са повредом кичмене мождине параплегијом које се рекреативно или професионално баве спортом.

Методологија рада: Узорак испитаника је чинило 26 особа са повредом кичмене мождине - параплегијом, оба пола, који се активно баве спортом, тренирају минимум 2-3 пута недељно. Истраживање је реализовано у Београду, и то у Дому за одрасла инвалидна лица, Удружењу параплегичара и квадриплегичара „Дунав“, Атлетском клубу „Погледи“, Клубу комаркаша у колицима „Дунав“, Стонотениском клубу особа са инвалидитетом Београда „СТИБ“ и Спортско-рекреативном удружену „Све је могуће“. За потребе истражсивана конструисан је упитник који је обухватио опште соиио-демографске карактеристике и архитектонске баријере на које наилазе бавећи се спортом.

\section{Summary}

Introduction: The realization of sports activities of persons with disabilities requires, above all, the accessibility of sports facilities and sports grounds. Architectural barriers are physical barriers within a built environment, which restrict or completely disable the wheelchair users.

The aim of the research was to examine which architectural barriers persons with spinal cord injuries-paraplegia who were engaged in sports recreationally or professionally encountered.

Methodology: The sample consisted of 26 persons with spinal cord injury-paraplegia, both gender, who were active in sports and trained at least 2-3 times a week. The research was conducted in Belgrade, in the Home for Adult Disabled Persons, in the Association of paraplegics and quadriplegic „Dunav", Athletic club „Pogledi", Wheelchair Basketball club „Dunav“, Table tennisclub for persons with disabilities of Belgrade „STIB" and the Sports and recreation association ,Everything is Possible". For research purposes, a questionnaire covering general sociodemographic characteristics and architectural barriers that persons encountered when they were engaged in sports was constructed.

Conclusion: The most common architectural barriers encountered by athletes with spinal cord injuries-paraplegia are unadjusted wheelchair ramps (73.1\%) and parking spaces (69.2\%).

\footnotetext{
${ }^{1}$ Др Драгана Кљајић, Висока здравствена школа струковних студија у Београду, Србија.

2 Проф. др Фадиљ Еминовић, Факултет за специјалну едукацију и рехабилитацију, Универзитет у Београду, Србија.

3 Др Слађана Арсић, Висока медицинска школа струковних студија у Ћуприји, Србија.

${ }^{4}$ Др Марија Трајков, Висока здравствена школа струковних студија у Београду, Србија.
} 
Закључак: Најчешће архитектонске баријере на које наилазе спортисти са повредом кичмене мождине - параплегијом су неприлагођене рампе $(73,1 \%)$ и паркингместа $(69,2 \%)$.

Кључне речи: спорт особа са инвалидитетом, особе са повредом кичмене мождине, архитектонске баријере.
Keywords: sport of persons with disabilities, persons with spinal cord injuries, architectural barrier.

\section{УВОД}

$\mathrm{C}$ порт има виталан значај за сваку заједницу и због тога су јавне власти свих нивоа у обавези да обезбеде развој спорта и поспеше учешће становништва у спортским активностима. (1) Примена спортских активности особа са инвалидитетом има своје значајно место у рехабилитацији и након ње због доказаног позитивног дејства на психичке и моторичке способности, као и на квалитет живота. $(2,3)$ Реализација спортских активности особа са инвалидитетом захтева пре свега приступачност спортских објеката и спортских терена, саобраћајница, набавку спортске опреме, финансијску подршку за набавку спортских помагала и опреме, едукацију стручног кадра и др. ${ }^{(4)}$

Приступачност значи да свако има једнак приступ изграђеном окружењу без дискриминације на основу нечијег нивоа способности. Може се дефинисати као могућност коју појединац на било којој локацији и са било којом способношћу има на располагању како би учествовао у одређеној активности или низу активности у оквиру изграђеног окружења. ${ }^{(5)}$

Спортски објекти спадају у јавне објекте и односе се на мање и веће дворане за различите спортове (са лоптом, на леду, у води), спортске затворене и отворене терене (за тенис, голф), стадионе (фудбалске, универзалне, атлетске), тркачке наткривене и ненаткривене стазе (бициклистичке, мотоциклистичке, аутомобилистичке). ${ }^{(6)}$ Да би спортски терени и објекти били приступачни за особе са инвалидитетом и друге особе смањене покретљивости, пре свега треба обезбедити приступачан локални јавни превоз и паркинг-простор. Затим, приступне путање и стазе, сигнализацију и путоказе (ван зграде спортског објекта и унутар ње), улазе и коридоре за кретање и холове, излазне коридоре, сва степеништа, лифтове и рампе, трибине и седишта, услужне просторије (укључујући тоалете, продавнице и радње, простор за јело и пиће, барове и продајне објекте, конференцијски и простор за пријеме). Поред физичких, важно је обезбедити и системе за пружање информација и подршке за особе са инвалидитетом, за издавање улазница и паркирање, услужне телефонске линије, клупске публикације и програме утакмица, план евакуације и сл. ${ }^{(7)}$

„Непрекинути ланац кретања“ као концепт значи да се особа са инвалидитетом може кретати слободно у свом дому, да може ићи до града, до било које зграде или простора који одабере, било којим превозним средством, и да се враћа кући без суочавања са баријерама. Континуитет, односно непрекинутост „ланца кретања“ је кључни елемент за омогућавање мобилности, а недостатак само једног елемента доводи до искључивања особа са инвалидитетом. ${ }^{(5)}$

Архитектонске баријере су просторне препреке унутар изграђеног окружења, које корисницима инвалидских колица ограничавају или у потпуности онемогућавају 
њихову самосталну употребу. Оне на различите начине отежавају кретање и редукују мобилност, а настају услед примене просторно-грађевинских параметара и последично недовољног простора потребног за манипулисање инвалидским колицима. Архитектонске баријере у спортским објектима се односе пре свега на непостојање приступа објектима у виду рампи и подизних платформи, на неприступачност трибинама, у свлачионицама и гледалишту, тоалетима. ${ }^{(6)}$

До недавно у Београду нису постојали приступачни базени за особе са инвалидитетом. Тек 2010. године уградњом лифта превазиђена је архитектонска баријера уласка у базен у Спортским центрима „Врачар“ и „25. мај“ (садашњи Спортски центар „Милан Гале Мушкатировић“). Такође су приступачни и Спортски центри „Шумице“, „11. април“ и хала „Пионир“, као и „Штарк“ арена. У богатим земљама постоје референтне организације за активан живот особа са инвалидитетом, које обезбеђују не само информације о могућностима за рекреацију, него и лоцирању доступних спортских, рекреативних и рехабилитационих програма. ${ }^{(8)}$

У нашој држави је укључивање особа са инвалидитетом у спортске активности регулисано бројним законским и другим актима, од којих је најзначајнији документ међународног јавног права Конвенција УН о правима особа са инвалидитетом. Она, потврђена законом Републике Србије, у члану 9 укључује приступачност која се односи на физичко окружење и превоз, приступачност информацијама и комуникацијама, и елиминацију препрека у изграђеном окружењу (Закон о потврђивању Конвенције о правима особа са инвалидитетом). У Преамбули, у члану 30 стоји да су се државе потписнице Конвенције УН обавезале да ће обезбедити учешће особама са инвалидитетом у спортском животу, рекреацији и слободним активностима применом одговарајућих мера. Између осталих, једна од најважнијих јесте обезбедити приступ спортским објектима и услугама оних који се баве организацијом спортских и рекреативних активности. ${ }^{(1)}$

Према Закону о спречавању дискриминације особа са инвалидитетом ${ }^{(9)}$ забрањена је дискриминација на основу инвалидности у погледу доступности услуга и приступа објектима у јавној употреби и јавним површинама. Приступачност саобраћајницама и јавним површинама регулисана је Законом о јавним путевима, ${ }^{(10)}$ којим се регулишу, између осталог, конструктивни елементи, као што су: ивичњаци, површине путева и тротоара, раскрснице, саобраћајна сигнализација, банкине и паркинг-места. Од значаја за приступачност изграђеног окружења је Правилник о техничким стандардима приступачности, ${ }^{(11)}$ који детаљно утврђује све обавезне елементе приступачности и елементе за савладавање висинских разлика, кретање и боравак у простору и елементе приступачности јавног саобраћаја.

Ипак, према извештају Светске здравствене организације из 2011. године, баријере на које наилазе особе са инвалидитетом су и даље присутне и утичу негативно на њихов квалитет живота. Пре свега се односе на непоштовање постојеће политике и утврђених стандарда, недостатак приступачности који се односи на транспорт и информационе системе, предрасуде и негативне ставове, као и недостатак учешћа особа са инвалидитетом у ангажовању и одлучивању у областима које директно утичу на њихов квалитет живота. ${ }^{(1)}$

Циљ истраживања је био да се испита на које архитектонске баријере наилазе особе са повредом кичмене мождине које се рекреативно или професионално баве спорTOM. 


\section{МЕТОДОЛОГИЈА РАДА}

У истраживању је учествовало укупно 26 особа са повредом кичмене мождине параплегијом, оба пола, старости између 20 и 60 година. Испитаници су прошли фазу рехабилитације, за кретање користе инвалидска колица и активно тренирају минимум 2-3 пута недељно у последњих годину дана.

Истраживање је реализовано у Београду, и то у Дому за одрасла инвалидна лица, Удружењу параплегичара и квадриплегичара „Дунав“, Атлетском клубу „Погледи“, Клубу кошаркаша у колицима „Дунав“, Стонотениском клубу особа са инвалидитетом Београда „СТИБ“ и Спортско-рекреативном удружењу „Све је могуће“".

Метод рада. За потребе истраживања конструисан је упитник који су самостално попуњавали испитаници. Упитник се састојао из два дела. У првом делу упитника обухваћене су основне информације о дијагнози и комплетности повреде кичмене мождине, врсти спорта, учесталости на недељном нивоу и спотским достигнућима.
Испитаницима је у другом делу упитника понуђен списак од 10 најчешћих архитектонских баријера на које наилазе особе са инвалидитетом, ${ }^{(6,12)}$ а они су имали задатак да потврде присуство истих на које наилазе приликом доласка на тренинг, тренирања и такмичења у спорту који тренирају. У истраживању је примењена дескриптивна статистика, а резултати су приказани табеларно и графички.

\section{РЕЗУЛТАТИ ИСТРАЖИВАЫА}

У истраживању је учествовало $19(73,1 \%)$ испитаника мушког пола и 7 (26,9\%) испитаника женског пола. Комплетну повреду кичмене мождине (ASIA A) имало je $16(61,5 \%)$ испитаника, а некомплетну повреду кичмене мождине (ASIA B, C) имало је 10 (38,5\%) испитаника. Просечна старост испитаника је за мушки пол износила 35,9 године, а за женски пол 43,2 године. Старост повреде, односно време протекло од повређивања кичмене мождине за испитанике мушког пола просечно је износило 14,2 године, а за испитанике женског пола 19,8 година (Табела 1).

Табела 1. Структура испитаника у односу на пол, комплетност повреде кичмене мождине, старост и време протекло од повређивања.

\begin{tabular}{|c|c|c|c|c|c|c|c|c|c|}
\hline \multirow{2}{*}{$\begin{array}{l}\text { Редни } \\
\text { број }\end{array}$} & \multicolumn{4}{|c|}{ ПОЛ } & \multicolumn{3}{|c|}{ ASIA A } & \multicolumn{3}{|c|}{ ASIA B, C } & $\begin{array}{l}\text { Старост } \\
\text { (године) }\end{array}$ & $\begin{array}{l}\text { С т а р о с т } \\
\text { повреде } \\
\text { (године) }\end{array}$ \\
\cline { 2 - 10 } & ПОЛ & Број & $\%$ & Број & $\%$ & Број & $\%$ & АС \pm СД* & АС \pm СД* \\
\hline 0 & 1 & 2 & 3 & 4 & 5 & 6 & 7 & 8 & 9 \\
\hline 1 & Мушки & 19 & 73,1 & 10 & 38,5 & 9 & 34,6 & $35,9 \pm 6,5$ & $14,2 \pm 6,7$ \\
\hline 2 & Женски & 7 & 26,9 & 6 & 23,1 & 1 & 3,8 & $43,2 \pm 8,5$ & $19,8 \pm 0,5$ \\
\hline 3 & Укупно & 26 & 100 & 16 & 61,5 & 10 & 38,5 & - & - \\
\hline
\end{tabular}

*АС - аритметичка средина; СД - стандардна девијација

У Табели 2. је приказано да већина испитаника живи у граду, где и тренира, укупно $88,5 \%$ испитаника, а само $11,5 \%$ испитаника живи на селу. Да би се превезли од куће до спортских објеката где тренирају, користе лични превоз - аутомобил (84,6\% испитаника), а само 15,4\% испитаника користи јавни превоз. 
Табела 2. Структура испитаника у односу на место становања и врсту превоза које користе приликом одласка на тренинге и такмичења.

\begin{tabular}{|c|c|c|c|c|c|c|c|c|c|}
\hline \multirow{2}{*}{$\begin{array}{l}\text { Редн и } \\
\text { број }\end{array}$} & \multirow{2}{*}{ Пол } & \multicolumn{4}{|c|}{ Место становања } & \multicolumn{4}{c|}{ Превоз } \\
\cline { 3 - 11 } & & \multicolumn{2}{|c|}{ Село } & \multicolumn{2}{c|}{ Град } & \multicolumn{2}{|c|}{ Лични } & \multicolumn{2}{c|}{ Јавни } \\
\cline { 3 - 11 } & & Број & $\mathbf{\%}$ & Број & $\mathbf{\%}$ & Број & $\mathbf{\%}$ & Број & \% \\
\hline 0 & 1 & 2 & 3 & 4 & 5 & 6 & 7 & 8 & 9 \\
\hline 1 & Мушки & 3 & 11,5 & 16 & 61,5 & 17 & 65,4 & 2 & 7,7 \\
\hline 2 & Женски & - & - & 7 & 26,9 & 5 & 19,2 & 2 & 7,7 \\
\hline 3 & Укупно & 3 & 11,5 & 23 & 88,5 & 22 & 84,6 & 4 & 15,4 \\
\hline
\end{tabular}

На Графикону 1. се види да је највећи број испитаника тренирало кошарку у колицима $(34,6 \%)$ и атлетику $(26,9 \%)$. По $11,5 \%$ испитаника је тренирало стрељаштво и стреличарство, 7,7\% испитаника је тренирало стони тенис, а по један испитаник је тренирао бициклизам $(3,8 \%)$ и боди билдинг $(3,8 \%)$.

Графикон 1. Дистрибуција испитаника у односу на врсту спорта који тренирају.

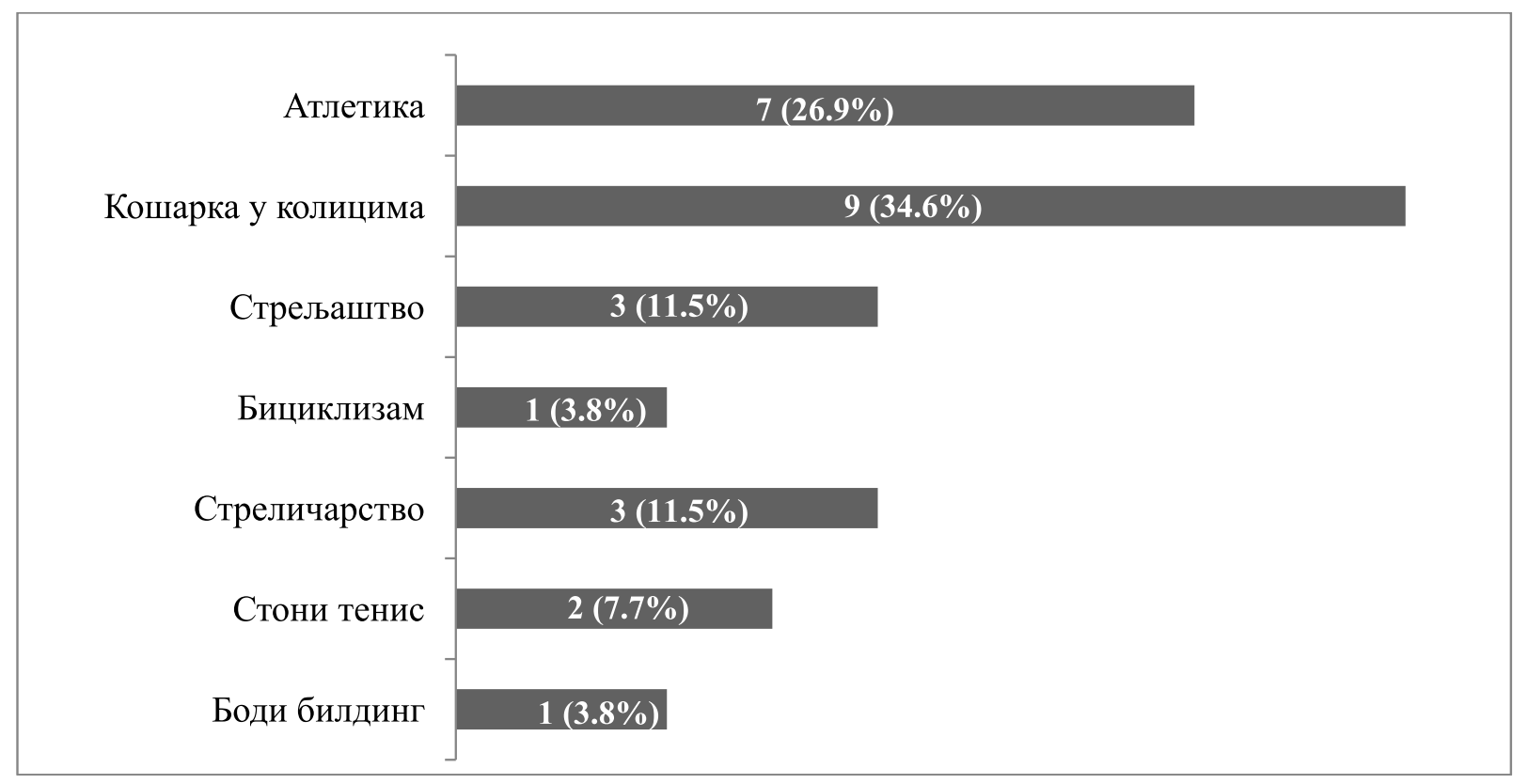

Табела 3. Структура испитаника у односу на пол, број тренинга на недељном нивоу и освојеним наградама.

\begin{tabular}{|c|l|c|c|c|c|c|c|}
\hline \multirow{2}{*}{$\begin{array}{c}\text { Редни } \\
\text { број }\end{array}$} & \multicolumn{1}{|c|}{$\begin{array}{c}\text { Број тренинга на недељном } \\
\text { нивоу }\end{array}$} & \multicolumn{2}{|c|}{ Мушки пол } & \multicolumn{2}{|c|}{ Женски пол } & \multicolumn{2}{|c|}{ Укупно } \\
\cline { 3 - 8 } & \multicolumn{1}{|c|}{$\begin{array}{c}\text { Број } \\
\text { \% }\end{array}$} & 2 & 3 & 4 & 5 & 6 & 7 \\
\hline 1 & $\begin{array}{l}2-3 \text { пута (кошарка у колицима, } \\
\text { стони тенис, бициклизам) }\end{array}$ & 10 & 38,4 & 2 & 7,7 & 12 & 46,1 \\
\hline 2 & $\begin{array}{l}4-5 \text { пута (стреличарство, } \\
\text { стрељаштво) }\end{array}$ & 1 & 3,8 & 5 & 19,2 & 6 & 23,1 \\
\hline
\end{tabular}




\begin{tabular}{|c|l|c|c|c|c|c|c|}
\hline 3 & 6-7 пута (боди билдинг) & 1 & 3,8 & - & - & 1 & 3,8 \\
\hline 4 & $8-12$ пута (атлетика) & 7 & 26,9 & - & - & 7 & 26,9 \\
\hline 5 & Укупно & 19 & 73,1 & 7 & 26,9 & 26 & 100 \\
\hline \multicolumn{7}{|c|}{ Награде } \\
\hline 6 & државне & 10 & - & 4 & - & 14 & - \\
\hline 7 & светске & 5 & - & 1 & - & 6 & - \\
\hline 8 & параолимпијске & 3 & - & - & - & 3 & - \\
\hline 9 & Укупно & 18 & - & 5 & - & 23 & - \\
\hline
\end{tabular}

Из Табеле 3. се види да је највећи проценат испитаника тренирао 2-3 пута недељно (46,1\%), а 8-12 пута недељно је тренирало $26,9 \%$ испитаника. Четири до пет пута недељно је тренинге имало $23,1 \%$ испитаника, док је само један испитаник тренирао 6-7 пута недељно (3,8\%). Највећи број награда је освојено на државним такмичењима (укупно 14), док је на светским првенствима медаљу освојило шест испитаника. На параолимпијским играма три испитаника су освојила неку од медаља.

Графикон 2. Дистрибуција испитаника у односу на архитектонске баријере на које наилазе при одласиима на тренинг и такмичења.

\begin{tabular}{|c|c|}
\hline Рампе (недостатак/неприлагођене) & $19(73.1 \%)$ \\
\hline $\begin{array}{c}\text { Паркинг места (заузети, удаљени, } \\
\text { необележени) }\end{array}$ & $18(69.2 \%)$ \\
\hline Јавни превоз (неприступачан) & $3(11.5 \%)$ \\
\hline $\begin{array}{c}\text { Врата (недовољна ширина, прагови, } \\
\text { отварање) }\end{array}$ & $10(38.5 \%)$ \\
\hline Неприлагођени тоалети & $10(38.5 \%)$ \\
\hline Неприлагођене туш кабине & $8(30.8 \%)$ \\
\hline Неприлагођене свлачионице & $9(34.6 \%)$ \\
\hline Уски ходници и пролази & $11(42.3 \%)$ \\
\hline Неравни терени & $12(46.1 \%)$ \\
\hline Неприлагођена места у гледалишту & $5(19.2 \%)$ \\
\hline
\end{tabular}

Из Графикона 2. се види да је недостатак/ неприлагођеност рампи $(73,1 \%)$ најчешћа баријера на коју наилазе спортисти са по- вредом кичмене мождине, затим следе паркинг-места (заузета, удаљена, необележена) (69,2\%) и неравни терени $(46,1 \%)$. 


\section{ДИСКУСИЈА}

Повреда кичмене мождине представља тежак степен инвалидитета, а учешће у спортским активностима доприноси побољшању квалитета живота, пре свега у области функционисања и расположења. ${ }^{(3)}$ Испитаници мушког пола су били просечне старости 35,9 година, женског пола 43,2 године (Табела 1), а приближну старост испитаника налазимо и у другим истраживањима где се спортом баве особе са различитим врстама инвалидитета. ${ }^{(13,14,15)}$

Баријере на које свакодневно наилазе особе са инвалидитетом могу да утичу како на постизање значајних резултата, тако и на мотивацију. Пре свега ту спадају персоналне баријере (недостатак енергије, замор), фактори животне средине (непостојање могућности бављења спортом, приступачност - архитектонске баријере, транспорт), недостатак информација о примени и карактеристикама спорта особа са инвалидитетом. ${ }^{(16,17)}$ У нашем истраживању највише присутне архитектонске баријере се односе на недостатак и неприлагођеност рампи $(73,1 \%)$, што је слично резултату истраживања из 2017. године $(76 \%) .{ }^{(12)} \mathrm{He}-$ достатак или неприлагођеност рампи у значајној мери ремети одласке на тренинг и такмичења, будући да се зна да свака препрека виша од $2 \mathrm{~cm}$ представља баријеру за особе које се крећу инвалидским колицима. ${ }^{(6)}$

Такође, у нашем истраживању је приказано да се испитаници крећу помоћу инвалидских колица, а на тренинге и у већини случајева одлазе сопственим превозом (Табела 2). Међутим, немогућност транспорта особа са инвалидитетом од куће до спортских објеката може да буде важан фактор неучествовања у спортским активностима, како наводе неки аутори. ${ }^{(18)}$

Како је претходно наведено, обезбеђена и обележена паркинг-места су, такође, основ за остваривање приступачности. Чак $69,2 \%$ испитаника сматра да заузет, удаљен и/или необележен паркинг значајно доприноси стварању климе неприступачности при бављењу спортом, што налазимо и у другим истраживањима. ${ }^{(15)}$ Такође, студије показују да постоје проблеми обележавања аутомобила који користе особе са инвалидитетом, где паркинг налепнице имају право да добију само особе са инвалидитетом које имају минимум $80 \%$ телесног оштећења. Нажалост, има доста примера да несавесни грађани паркирају на обележена места за особе са инвалидитетом. ${ }^{(19)}$

Неприлагођена места у гледалишту су, такође, архитектонске баријере на које наилазе наши испитаници, и то се односи на трибине на којима се не очекује и трибинама где се очекује устајање навијача. Исто важи и за непостојање места у гледалишту која су пристпачна за особе које користе инвалидска колица. Да би се обезбедило приступачно гледалиште, треба да постоји тзв. инклузивни план седења, прилагођена и лако доступна седишта, простор за кориснике инвалидских колица и др. ${ }^{(7)}$ Како истичу неки аутори, поред недостатка прилагођених објеката значајну баријеру за примену спортских активности представљају и високи трошкови набавке одговарајуће опреме. ${ }^{(13,14)}$

Постојање неравних терена фактор је баријера код 46,2\% испитаника, а по $38,5 \%$ испитаника је навело да им значајне архитектонске баријере представљају врата и тоалети. Уски ходници и пролази ограничавају кретање у спортским објектима код 42,3\% испитаника, а неприлагођене туш-кабине и свлачионице представљају архитектонску баријеру код 30,7-34,6\% испитаника. Поменуте архитектонске баријере утичу на неометано коришћење спортских објеката, а недостатак прилагођених објеката као значајну баријеру наводе у својим истраживањима и други аутори. ${ }^{(20)}$

Неприступачност јавног превоза као баријеру је означило три испитаника, међутим, истраживања показују да су најчешћи проблеми јавног превоза особа са инвалидитетом пре свега мали број 
приступачних аутобуса и трамваја и непостојања рампи за улазак у њих. ${ }^{(19)}$

Највише испитаника је тренирало кошарку у колицима (34,6\%; Графикон 1), а највећи број тренинга су имали атлетичари (8-12 пута недељно; Табела 3). Импозантно је да више од половине наших испитаника има неку од награда у спорту који тренирају. Вероватно се то може приписати великом ентузијазму, али и позитивним ефектима на смањење компликација које се јављају код повреде кичмене мождине. Нажалост, неке студије показују да поред архитектонских постоје и друге баријере које утичу на бављење спортом. Оне се односе на недостатке асистенције и знања о начину примене спортских активности особа са инвалидитетом ${ }^{(13,20)}$ и недостатке подршке породице и пријатеља. ${ }^{(15)}$.

\section{ЗАКЉУЧАК}

Праћење, анализа и вредновање резултата о укључености особа са инвалидитетом у спортске активности је важно због унапређења спорта и уклањање постојећих архитектонских баријера. Најчешће архитектонске баријере на које наилазе особе са повредом кичмене мождине - спортисти у нашем истраживању су недостатак/не-

\section{ЛИТЕРАТУРА}

1. Оташевић Ј., Кљајић Д. Особе са инвалидитетом и њихова права у спорту. Правни живот, тематски број „Право и достојанство“, Београд, 2013; 1(9): 633-645.

2. Eminović F., Kljajić D. Effects of applied physical exercise on the motor abilities of people with spinal cord injury.

In: F. Eminović, M. Dopsaj (Ed.). Physical activity effects on the anthropological status of children, youth and adults. NewYork:

Nova Publishers, 2016: 129-161. прилагођеност рампи и заузета/удаљена/ необележена паркинг-места. За уклањање постојећих архитектонских баријера неопходно је пооштрити контролу примене техничких стандарда приступачности и подржати адаптацију спортских објеката како би се задовољили принципи приступачности и самим тим створили услови за укључивање већег броја особа са инвалидитетом у спорт.

Императив савременог друштва је обезбедити окружење без баријера, било да су оне персоналне, психо-социјалне или архитектонске. Свакако је то тема којом се баве не само политичари, архитекте и правна лица, него и особе које учествују у рехабилитацији особа са инвалидитетом, као што су физиотерапеути, радни терапеути, дефектолози и други.

Овај рад због малог узорка испитаника можда не приказује праву слику постојања архитектонских баријера на које наилазе особе са инвалидитетом, али је значајан за особе са повредом кичмене мождине - параплегијом. Пре свега због уочавања најчешћих архитектонских баријера, специфичности у односу на мобилност у „непрекинутом ланцу кретања“, а упркос томе наградама као сатисфакцији коју спорт пружа.
3. Kljajić D., Eminović F., Dopsaj M., Pavlović D., Arsić S., Otašević J. The impact of sports activities on quality of life of persons with a spinal cord injury. Zdravstveno Varstvo, 2016; 55 (2): 94-101.

4. Касум Г., Мијић 3. Значај школског физичког васпитања у анимирању и селектирању спортиста са инвалидитетом. Међународна научна конференција „Теоријски, методолошки и методички аспекти такмичења и припреме спортиста, Београд, Зборник радова, 2008; 219-225.

5. Disability Monitor Initiative South East Europe. Слободно кретање особа са 
инвалидитетом у југоисточној Европи: Неприступачно право? Београд, Hendicap International за југоисточну Европу, 2006.

6. Фејзић Е., Фејзић И. Хуманизирање изграђене околине - просторне баријере. Сарајево, Архитектонски факултет, 2016.

7. Приступ за све - UEFA и CAFE водич са препорукама за прављење приступачног стадиона и омогућавање равноправног доживљаја утакмице за све. Нион, Унија европских фудбалских савеза (UEFA) UEFA, SPORTSFILE, PA Archive, 2011.

8. Остваривање права особа са инвалидитетом - примери добре праксе. Београд, Заштитник грађана, 2011.

9. Закон о спречавању дискриминације особа са инвалидитетом. Сл. гласник РС $33 / 2006$.

10. Закон о јавним путевима. Сл. гласник PC 101/2005, 123/2007, 101/2011, 93/2012.

11. Правилник о техничким стандардима приступачности. Сл. гласник РС 46/2013.

12. Кљајић Д., Трајков М., Поповић J. Особе са инвалидитетом и архитектонске баријере. V стручно-научни скуп са међународним учешћем „Актуелности у едукацији и рехабилитацији особа са сметњама у развоју“. Ваљево, Зборник резимеа, 2017; 77.

13. Froehlich K., Nary DE, White GW. Identifying barriers to participation in physical activity for women with disabilities. SCI Psychosocial Process, 2002; 15(1): 21-29.

14. Levins SM, Redenbach DM, Dyck

I. Individual and societal influences on participation in physical activity following spinal cord injury: a qualitative study.

Physical Therapy, 2004; 84(6): 496-509.

15. Rimmer JH, Riley B., Wang E., Rauworth A., Jurkowski J. Physical activity participation among persons with disabilities: barriers and facilitators. American Journal of Preventive Medicine, 2004; 26(5): 419-425.

16. Jaarsma EA, Dijkstra PU, Geertzen JHB, Dekker R. Barriers to and facilitators of sports participation for people with physical disabilities A systematic review, Scandinavian Journal of Medicine \& Science in Sports, 2014; 24: 871-881. 17. Mulligan HF, Hale LA, Whitehead L., Baxter GD. Barriers to physical activity for people with long-term neurological conditions: A review study, Adapted Physical Activity Quarterly, 2012; 29: 243-265.

18. Ban der Ploeg HP, van der Beek AJ, van der Woude LHV, van Mechelen W. Physical activity for people with a disability: a conceptual model. Sports Medicine (Auckland, N.Z.), 2004; 34(10): 639-649.

19. Надгледај своја права: мониторинг права особа са инвалидитетом у Републици Србији: холистички извештај. Нови Сад, Центар за оријентацију друштва ЦОД, 2013.

20. Kinne S., Patrick DL, Maher EJ. Correlates of exercise maintenance among people with mobility impairments. Disability and Rehabilitation, 1999; 21(1): $15-22$.

Контакт: Др Драгана Кљајић, Цара Душана 254, 11080 Београд, Србија, тел.+381 (11) 2618-120,+381 (11) 2618-024, e-mail: draganakljajic76@gmail.com 